Original scientific paper

\title{
HOW TO EVALUATE LOCAL ECONOMIC DEVELOPMENT PROJECTS FROM A PEOPLE-CENTRED PERSPECTIVE? AN ANALYTICAL FRAMEWORK BASED ON THE CAPABILITY APPROACH
}

\author{
Judit GÉBERT ${ }^{\mathrm{a}}$, Zoltán BAJMÓCY ${ }^{\mathrm{b}}$, György MÁLOVICS ${ }^{\mathrm{c}}$ \\ ${ }^{a}$ University of Szeged, Faculty of Economics and Business Administration, e-mail: gebert.judit@eco.u- \\ szeged.hu \\ ${ }^{\mathrm{b}}$ University of Szeged, Faculty of Economics and Business Administration, e-mail: bajmocyz@eco.u- \\ szeged.hu \\ ${ }^{\mathrm{c}}$ University of Szeged, Faculty of Economics and Business Administration, e-mail: malovics.gyorgy@eco.u- \\ szeged.hu
}

Cite this article: Gébert, J., Bajmócy, Z., Málovics, G. (2017). How to Evaluate Local Economic Development Projects from a People-Centred Perspective? An Analytical Framework Based on the Capability Approach. Deturope, 9, 2: 4-24

\begin{abstract}
The present paper argues that the capability approach of Amartya Sen provides a meaningful contribution in understanding, evaluating and improving the well-being effects of local development projects. It focuses on what people can actually achieve, instead of what they have; and places equal attention to the process and the outcomes of the development process. The paper develops an analytical framework to evaluate local development projects, which is fine-tuned for middle and high income settings and allows comparison between cases. The framework is applied to three local development projects in a middlesized city in Hungary. We found that the rich informational basis of the capability-based perspective helps to identify the places for intervention: the barriers, which prevent people from actually using the newly created means (the results of the development projects), and the valued options of citizens either unaddressed or neglected by the development projects.
\end{abstract}

Keywords: Capability approach, local development, analytical framework, opportunity aspect, process aspect

\section{INTRODUCTION}

Contemporary discussions in regional science about development are often organized around the idea of competitiveness (Capello, 2009). The ability of a locality to achieve and sustain a role in the international division of labour (in the territorial competition generated by globalization) seems to be a vital consideration (Begg, 1999; Cox, 1995; Lever, 1999). Accordingly, local economic development projects - like building an industrial park, a shopping mall or upgrading a touristic attraction - are dominantly evaluated from a competitiveness or growth-centred paradigm. Here the question is: to what extent the given project contributes to the competitiveness (employment or economic growth) of the region? This dominant approach is reflected - inter alia - by the World Bank's documents: " $[\mathrm{t}] \mathrm{he}$ 
purpose of local economic development is to build up the economic capacity of a local area to improve its economic future and the quality of life for all.“ (Swinburn, Goga, \& Murphy, 2006).

While the rhetoric often highlights quality of life and livable cities, the task of the players in local economic development is still very much to operate the urban growth machine (Kirkpatrick \& Smith, 2011). This approach is perceived to be value-free, assuming that while people may disagree about values, there is no real reason to disagree about growth or competitiveness (Bajmócy \& Gébert, 2014). Furthermore, the competitiveness-based approach assumes a positive relationship between real income growth (or performance in global competition) and common good or well-being: whatever well-being is for individuals, it is definitely expanded by income growth.

The limitations of this competitiveness-based approach are easy to identify. First, the content of quality of life or well-being of local inhabitants remains vague. However, another sub-discipline of economics, the so-called welfare economics analyses these notions in detail. Second, the growth-centred view cannot be perceived as value-free since the desirability of increasing income is a value in itself (Hausman \& McPherson, 1997). In addition, to make an evaluative judgement about the collective well-being effects of the development projects, interpersonal comparison must be carried out. For this purpose, a commitment towards an informational basis of comparison is inevitable, which is again a value choice (Bajmócy \& Gébert, 2014). Third, the competitiveness-based approach is supported by the ideology that conflates urban growth with common good and well-being of local inhabitants. However, this relationship between real income and well-being is questioned from many perspectives (Easterlin, 1974; Stiglitz, Sen, \& Fitoussi, 2009).

There are two kinds of arguments about the relationship between well-being and realincome. According to the first type, the positive relationship between real-income and wellbeing exists, but economic growth has externalities, unintended side-effects. Therefore, the costs of growth may outweigh its benefits, even on a city-wide level (Greenwood \& Holt, 2010; Kirkpatrick \& Smith, 2011). According to the other type of arguments, real-income in itself is just means to achieve well-being (Sen, 2005). What really matters are individually valued doings and beings, like reading, writing, going for a holiday, being educated or taking part in the life of the community, etc. Accordingly, the relationship between real-income and valuable doings and beings is not direct. There are several conversion factors that influence how people can use their means in order to achieve different functionings. For instance, a person may not be able to attend education in case she or he suffered from racial, religious or gender discrimination, even if she or he had the necessary income to pay for it 
Therefore, the competitiveness-centred approach provides a view about local economic development projects that is too narrow, since these projects are embedded in complex social, economic and environmental situations. This is especially true in times when the global economy is shaken by fiscal crises (Greenwood \& Holt, 2010; Kirkpatrick \& Smith, 2011).

The present paper builds on the capability approach of Amartya Sen (1999) to provide an alternative (people-centred) approach to analyse and evaluate local economic development projects. As a consequence, it fits into an emerging stream of literature (Bajmócy \& Gébert, 2014; Biggeri \& Ferrannini, 2014b; Crocker, 2007), which attempts to approximate regional science and the capability approach. The paper attempts to contribute to the present discussions about local development in three ways. (1) First, it provides an evaluative framework of development initiatives that focuses on the expansion of people's real opportunities (capabilities). This way it assigns a substantive meaning to well-being. (2) On this basis, it develops a framework that gives equal attention to the process aspect of local development instead of just focusing on its outcomes. (3) Finally, it provides a capability approach based empirical evidence from a relatively high income region, contrary to the majority of capability-based local analyses. Carrying out analyses in high income setting on the basis of the capability approach (either regarding poverty or well-being) has just begun to appear in the literature (Rippin, 2016; Vizard \& Speed, 2016). The majority of related empirical findings still derive from low income setting (many of these attempts will be mentioned later in the paper).

In the second section of the paper we provide a brief overview of the capability approach and argue that it is appropriate to be used as a basis of an evaluative framework. The third section describes the analytical framework we developed based on the capability approach. In the fourth section we apply this framework to evaluate three local economic development projects in Szeged, Hungary. Finally, we draw our conclusions.

While the rhetoric often highlights quality of life and livable cities, the task of the players in local economic development is still very much to operate the urban growth machine (Kirkpatrick \& Smith, 2011). This approach is perceived to be value-free, assuming that while people may disagree about values, there is no real reason to disagree about growth or competitiveness (Bajmócy \& Gébert, 2014). Furthermore, the competitiveness-based approach assumes a positive relationship between real income growth (or performance in global competition) and common good or well-being: whatever well-being is for individuals, it is definitely expanded by income growth.

The limitations of this competitiveness-based approach are easy to identify. First, the content of quality of life or well-being of local inhabitants remains vague. However, another sub-discipline of economics, the so-called welfare economics analyses these notions in detail. 
Second, the growth-centred view cannot be perceived as value-free since the desirability of increasing income is a value in itself (Hausman \& McPherson, 1997). In addition, to make an evaluative judgement about the collective well-being effects of the development projects, interpersonal comparison must be carried out. For this purpose, a commitment towards an informational basis of comparison is inevitable, which is again a value choice (Bajmócy \& Gébert, 2014). Third, the competitiveness-based approach is supported by the ideology that conflates urban growth with common good and well-being of local inhabitants. However, this relationship between real income and well-being is questioned from many perspectives (Easterlin, 1974; Stiglitz, Sen, \& Fitoussi, 2009).

There are two kinds of arguments about the relationship between well-being and realincome. According to the first type, the positive relationship between real-income and wellbeing exists, but economic growth has externalities, unintended side-effects. Therefore, the costs of growth may outweigh its benefits, even on a city-wide level (Greenwood \& Holt, 2010; Kirkpatrick \& Smith, 2011). According to the other type of arguments, real-income in itself is just means to achieve well-being (Sen, 2005). What really matters are individually valued doings and beings, like reading, writing, going for a holiday, being educated or taking part in the life of the community, etc. Accordingly, the relationship between real-income and valuable doings and beings is not direct. There are several conversion factors that influence how people can use their means in order to achieve different functionings. For instance, a person may not be able to attend education in case she or he suffered from racial, religious or gender discrimination, even if she or he had the necessary income to pay for it

Therefore, the competitiveness-centred approach provides a view about local economic development projects that is too narrow, since these projects are embedded in complex social, economic and environmental situations. This is especially true in times when the global economy is shaken by fiscal crises (Greenwood \& Holt, 2010; Kirkpatrick \& Smith, 2011).

The present paper builds on the capability approach of Amartya Sen (1999) to provide an alternative (people-centred) approach to analyse and evaluate local economic development projects. As a consequence, it fits into an emerging stream of literature (Bajmócy \& Gébert, 2014; Biggeri \& Ferrannini, 2014b; Crocker, 2007), which attempts to approximate regional science and the capability approach. The paper attempts to contribute to the present discussions about local development in three ways. (1) First, it provides an evaluative framework of development initiatives that focuses on the expansion of people's real opportunities (capabilities). This way it assigns a substantive meaning to well-being. (2) On this basis, it develops a framework that gives equal attention to the process aspect of local development instead of just focusing on its outcomes. (3) Finally, it provides a capability approach based empirical evidence from a relatively high income region, contrary to the 
majority of capability-based local analyses. Carrying out analyses in high income setting on the basis of the capability approach (either regarding poverty or well-being) has just begun to appear in the literature (Rippin, 2016; Vizard \& Speed, 2016). The majority of related empirical findings still derive from low income setting (many of these attempts will be mentioned later in the paper).

In the second section of the paper we provide a brief overview of the capability approach and argue that it is appropriate to be used as a basis of an evaluative framework. The third section describes the analytical framework we developed based on the capability approach. In the fourth section we apply this framework to evaluate three local economic development projects in Szeged, Hungary. Finally, we draw our conclusions.

\section{The capability approach}

The capability approach is a theory of well-being. It was initially developed by the Nobellaureate Amartya Sen in the 1990s, who formulated strong critiques against mainstream economics. In contrast with the utilitarian, growth or competitiveness-centred views, the capability approach focuses on the real opportunities of people: what they can actually do and what they can actually be with the help of their means (Sen, 1999). These feasible options are called capabilities. In the capability approach, human development means the broadening of capabilities, i.e. creating more and more opportunities to choose from.

The central notion in Sen's approach is the term "capability", which refers to the actual freedom to achieve valuable doings and beings. For this purpose people need means (e.g. income, infrastructure). But the possession of means does not imply the freedom to achieve our goals. A number of conversion factors may influence how we can use our means. Conversion factors can be manifold, for instance, personal characteristics like age, gender; environmental characteristics, like pollution; and social behaviours, like racial discrimination (Sen, 1999).

So from the perspective of the capability approach, real income is just means to achieve valuable doings and beings but not and end in itself. For example, a disabled person cannot achieve the same opportunities as a healthy one with the same amount of wealth because the person with disability has to spend (probably a lot of) money on special medical devices or treatments. Therefore, less remains for a disabled person to achieve her own goals than for a healthy person (Sen, 1999).

In the capability approach, agency is a special capability it means the ability to further our own goals (Alkire, 2007). Sen emphasizes that people are agents of change and not just simple patients (recipients) of the development processes. As a consequence, in the capability approach, public participation and deliberation have special importance: they provide the 
opportunity for people to act as agents of change and can help to determine the most valuable opportunities for the involved/affected community. However, it is apparent that people do not have equal possibilities to further their ends. Therefore the idea of empowerment (to make people capable of acting as agents) is central for the capability approach (Mayo, 2004).

The capability approach is a normative and value-laden approach. It means that it gives a substantive meaning to the notion of well-being. It is also committed to the value of choice. Capability is the freedom to choose something valuable (for instance the freedom to choose to be educated) and it is not the achievement itself (to be educated). Sen (1995) emphasizes that values need to be made explicit and be scrutinized through social deliberation. The capability approach is pluralistic in the sense that it takes into consideration diverse social values via social deliberation and realizes that people are of different characteristics.

The capability approach has had impacts on several fields of social sciences. It has been used to evaluate human development of countries or regions and development projects in lowincome countries; to assess poverty; to analyse impact of technological change; to scrutinize the situation of disabled people; and to consider gender inequality and social norms (Alkire, 2007).

In the literature, there are several examples of analysing development projects in lowincome countries in line with the capability approach (Biggeri \& Ferrannini, 2014a; Cotula, 2008; Frediani, 2007; González, Aristizábal, \& Díaz, 2008; Hartono, 2012; Hodgett, 2008; Kerstenetzky \& Santos, 2009; Nieto \& Munoz, 2012; Pellissery \& Bergh, 2007; Schischka, Dalziel, \& Saunders, 2008). These studies conclude that the analysed development projects in low-income countries usually follow some kind of "project-logic". The projects are often unsuccessful because they focus only on providing means (in most of the cases physical infrastructure). Decision-makers do not assess unintended side-effects, underestimate the complexity of social situations, do not take notice of hidden social relations, sometimes intensify social inequalities, and homogenize people. In contrast, the capability approach focuses on how people can use their means and what kind of values they have.

\section{Analytical framework}

There already are a number of analytical frameworks to evaluate local economic development projects on the basis of the capability approach (Biggeri \& Ferrannini, 2014b; Frediani, 2007; Hartono, 2012). However, these frameworks are fine-tuned for analysing projects that provide basic opportunities (e.g. housing or sanitation) in low-income countries. In addition, these frameworks were not developed to serve as a basis for the comparison of different cases on a unified basis. 
Figure 1 Analytical framework based on the capability approach

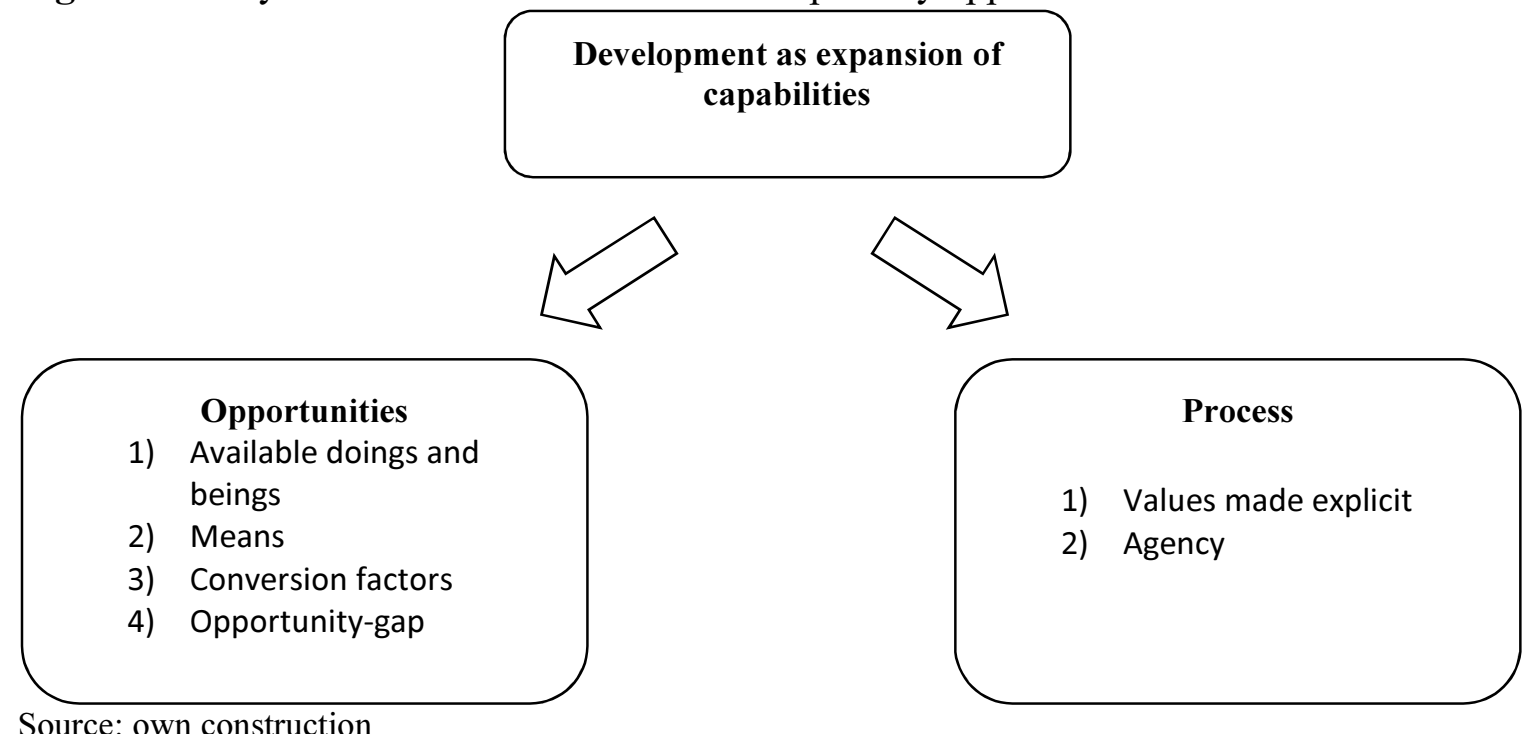

The main goal of our framework is to evaluate local economic development projects in middle or high income countries, and in the same time to allow comparison with the previously documented case studies (Fig. 1.). The basis of the framework is the understanding of development as the expansion of capabilities. The two building blocks are based on Alkire's (2007) idea about the opportunity aspect and the process aspect of development. The opportunity aspect refers to the widening of the set of valuable choices for the local inhabitants. The process aspect highlights that the processes through which development is accomplished also matter, beside the "doings and beings" made available. Accordingly, the questions of "what" to develop must be supplemented by the questions of "who" and "how".

The first element of the opportunity aspect of our analytical framework reveals the valuable doings and beings made available by the development projects. It shows what stakeholders can actually do with their newly available means. For instance, solar power plants allow local inhabitants to use electric devices, watch television, or read at night (González, et al., 2008).

The capability approach is built on the distinction between possessing certain means and actually being able to use them. Although the capability approach focuses on the valuable doings and beings, the means made available by the development projects also require attention. The same set of means may make very different opportunities available depending on the context in which they are used.

Most the development projects are means-based. They focus on the provision of means instead of how people can actually use them (Frediani, Boni, \& Gasper, 2014). The difference between a competitiveness-based and a capability-based evaluation becomes apparent here. Means are understood here as resources, which can be used to broaden the individual's capabilities. Means can be tangible (e.g. a building) or abstract (e.g. laws). 
The next element of the evaluative framework is the group of conversion factors. Conversion factors can be personal or external. They influence how individuals can use their means, how they can achieve valuable doings and beings (Sen, 1999). Individuals have the actual opportunity to achieve functionings, if (1) they have access to the necessary means and (2) the circumstances are adequate to use them. Thus, conversion factors are often barriers which prevent people from utilizing their means to pursue their own ends. One of the most important messages of the capability approach for decision makers is that it is necessary to identify and remove these conversion factors. This again highlights that according to the capability approach development demands more than only providing resources for communities.

The fourth element of the opportunity aspect of our analytical framework is the so-called opportunity-gap. Opportunity-gap is the set of choice options, which are unavailable for the community at the moment but they have good reasons to value them (Biggeri \& Ferrannini, 2014a). The notion of opportunity-gap is relevant for the evaluative framework because it can reveal those capabilities that are valuable but missing. For example, a community may value recreation opportunities on the riverside but without the necessary infrastructure - roads, showers, benches, trash cans, toilettes - they cannot actually achieve them (or at least not at the required standard). In this case the task of decision-making is to realize the valuable functioning (to have recreation activities on the riverside), and make these opportunities available by identifying and breaking down the barriers.

The opportunity gap also highlights that the members of the community may not be equally able to achieve a given opportunity. For instance, if a public building is not accessible, then people with certain disabilities will have reduced possibilities to access the given public services.

The idea of the opportunity-gap also embraces those capabilities which are threatened due to the local development initiatives. Usually, development projects both create and destroy opportunities at the same time. Valuable but disappearing opportunities also need to be taken into consideration during the evaluation of local economic development.

The second building block of our framework is the process aspect. According to the capability approach, the process aspect is important because people are not simple recipients or patients of development but active agents who can act according to their reasons (Frediani, et al., 2014; Sen, 1999). On the one hand, people may assign value to the fact that they were able to actively participate. This way, taking part in the development process becomes a component of well-being. On the other hand, participation may help people to bring about outcomes that are more desirable for them (Sen, 1999). 
According to Sen, the values of individuals must be made explicit and must be openly discussed (Sen, 1995). This has two reasons. First, none of the development interventions are value neutral, not even the economic growth-centred policy decisions (Bajmócy \& Gébert, 2014; Hausman \& McPherson, 1997). Therefore, the values must be made explicit and must be the subject of open public debates. Second, people's values often influence how they can use their available means. Accordingly, the success of development depends on the values of local inhabitants. For instance, in the case of the upgrading of a marketplace, the preferred infrastructure and programmes will highly depend on whether the market is understood to be a competitor of the shopping malls or a traditional community place.

The opportunity to further our own ends is called agency. It is one of the most important components of the capability approach. Therefore, a development process should aim at helping people to be able to pursue the common good, articulate their values, opinions and take an active part in the development process. As a consequence, not just the achieved functionings or the actual choice options (capabilities) matter, but also the process, through which the community achieved those capabilities.

In our evaluative framework, the process aspect consists of two elements: agency and the values made explicit. It is not easy to evaluate the extent of agency: the extent of freedom to influence the decisions about one's life. The literature suggests some approaches to tackle this problem, such as Arnstein's ladder (and its modified versions) about actual political participation (Arnstein, 1969; Pretty, 1995) or the distance from the power center (Maier, 2001). We decided to use Gaventa's (2006) power cube, which is based on the literature of power structures. In Gaventa's understanding, political influence means the "capacity to participate effectively in shaping the social limits that define what is possible" and power means "network of social boundaries that delimit fields of social action" (Gaventa, 2006, p. 26). These notions seem to be close to the idea of "freedom for agency", thus we believe it is appropriate to integrate the power cube into our analytical framework about the expansion of capabilities.

The power cube consists of three dimensions the spaces, forms and levels of power. Under spaces of power Gaventa (2006) understands those opportunities or channels through which citizens can act in order to influence decisions, discourses and relationships in their life. It is important to emphasize that the spaces of power are not fixed. They are dynamically changing instruments made by humans to use power.

There are three different kinds of spaces in the power cube: closed, invited and claimed spaces. A closed space is a space of decision-making, in which a closed group makes the most important decisions behind closed doors without involving any other actors into the process. For instance, a city council can be a closed space, if it does not invite any other stakeholders 
into the decision-making process. Part of the civil society works in order to disrupt or open up these spaces and to ensure publicity and transparency. Invited space means that the main decision-making institution invites other actors, individuals or organizations into the process. Invited spaces usually have some kind of organized form, like a residential forum. Claimed spaces are those spaces of power that are claimed by less powerful groups of the society. It means that they act upon to gain space in decision-making. People with similar values and mind-sets but without power join forces to achieve a common goal. Those spaces can be manifold: from social movements, through founding non-governmental organisations (NGOs) to community spaces like a local pub, where people discuss certain issues.

These spaces are linked together and are dynamically changing. For instance, a local, bottom-up social movement can transform into a formal organisation (an NGO) and become an invited player in decision-making. Claimed spaces have significance, because these are the spaces through which new values, ideas or opinions can be channelled into decision-making.

The second dimension of the power cube is the forms of power (Gaventa, 2006). On the basis of its manifestations, it differentiates between visible, hidden and invisible forms. Visible power denotes the observable and defined form of power (e.g. formal rules, structures; authorities, institution and other official mechanism of decision-making). Hidden power means the capacity to influence the agenda of decision-making. Power is not just a capacity to make a decision in a case but to prevent the case from arising as a problem at all (Lukes, 1974). Generally, less influential groups are left out because of the mechanisms of hidden power. Invisible power refers to the capacity to determine the psychological or ideological boundaries of political participation and to influence the interpretations of problems and the norms of overall acceptance. Sometimes, serious problems are missing not just from the political agenda but also from the perceptions of the stakeholders. These channels affect how people think about their position in the world, what they believe to be acceptable. For example, it is a common phenomenon, that the local elite dominate the development projects in low-income countries (Frediani, 2010). Although they use the projects according to their own self-interest, for the local inhabitants this situation is the status quo, and they do not think that it could change or that they should speak out for their own interests.

The third dimension of the power cube is the levels of power. According to Gaventa (2006) the level can be local, national or global. In the literature, there are arguments for initiating political participation at local level but others claim that participating at the global level is inevitable because nowadays power is concentrated in the hands of global actors (Nussbaum, 2011). Nevertheless, in case of evaluating local development projects, the local level always plays a vital role. 
The three dimensions of power draw attention to the different strategies or spaces where civil society can intervene and gain power in decision-making. Some of the NGOs work between visible and formal spaces; for example, they take part in residential forums or deliver official opinion about development plans. Other parts of the civil society focus on mobilizing people, developing collective action plans to overcome difficulties about hidden power and raise awareness for social problems. An action can be for example a photo-voice exhibition about the life-circumstances of local segregated groups. Other civil groups make efforts to approach invisible forms of power so that they emphasize social values like equality or religious tolerance.

The power cube is created by putting together the three dimensions. The individual components can be analysed one by one or together with the others. The categories within the dimensions are not strictly separated; on the contrary, they are part of an adaptive continuum. In our paper, we use the dimension of spaces to demonstrate our results but we also take into consideration the other two dimensions.

\section{METHODOLOGY AND CASE DESCRIPTION}

The objective of our empirical research is to evaluate local economic development projects from the aspect of the capability approach with the help of our analytical framework. So the focus of our research is to reveal the social, economic and environmental circumstances and to understand the link between them.

This pursuit called for a qualitative and inductive research design, but it incorporated abductive elements as well, because we attempted to understand specific explanations of concrete cases through the interpretations of the local actors, to find the best possible accounts of social phenomena (Blaikie, 2000; King, Keohane, \& Verba, 1994).

We analysed three cases with the help of our people-centred evaluative framework: (1) the building of a shopping mall, (2) the building of a water park and spa, and (3) the rebuilding of a marketplace. All the three cases are located in Szeged, a middle-sized city in Hungary, being a regional centre with 161000 inhabitants.

The shopping mall (called Árkád) was constructed between 2010 and 2013. It is now the biggest shopping mall of the region. The site, on which it was built, had served as premises for a hemp-spinning factory, a post office, an apartment building and a kindergarten. The shopping mall is owned by a private company.

The new water park and spa (called Napfényfürdö Aquapolis) is situated near the city centre at the riverside. Previously on the site, there had been an old thermal bath and swimming pool used for professional and amateur sporting. Now, the new water park and spa 
is a complex of different wellness services connected to water. $20 \%$ of the spa is owned by a wellness hotel, which is connected to the spa; the other $80 \%$ is in the possession of the city. The spa was constructed between 2008 and 2014.

The rebuilt marketplace (called market on the Mars square) is the biggest marketplace of the city. The venue has been functioning as a market since the middle of the 20th century. It is near the city centre and is located next to a regional and local bus station. The renewal had been on the political agenda since the 1990's but it was realized only in the past few years. The reconstruction took place between 2004 and 2012.

The empirical research consists of two steps. First, local documents - press releases, reports, court orders, open letters and contracts - were analysed with the help of content analysis. It helped to identify the stakeholders of the projects. Second, we conducted semistructured in-depth interviews with the stakeholders. We carried out so-called "traveller" interviews, where the structure of the conversation is strongly shaped by the interviewee, she is the one who introduces new topics; the interviewer only asks for more information in connection with topics that have already emerged (Brinkmann \& Kvale, 2015). In the first phase of interviewing, we asked the stakeholders identified through the content analysis. Afterwards, we continued with snowball sampling.

Altogether 31 interviews were conducted for the three cases between 2013 October and 2014 April. Since Szeged is a middle-sized city, all the interviewees were affected by all of the three projects, at least as users. Among the interviewees, there were 9 civic activist, 4 simple users, 10 local politicians, and 8 experts. Certainly, these categories refer to the most relevant role of the interviewees; the boundaries are not always sharp. For instance, a civic activist can also be a user, or a local politician can take part in bottom-up initiatives. Experts are locals who are connected to the development project as a consequence of their expertise, like water management engineers, architects, economists working for local public institutions and managers of the project. Among the interviewees, there were 29 men and 2 women.

\section{RESULTS}

We demonstrate the results of the three case studies jointly, in accordance with the analytical framework and we support the results with quotes from interviews. We numbered our interviews from V1 to V31. Besides numbers, we also indicate in the text the most important role of the interviewee. We first focus on the opportunity aspect, then evaluate the process aspect of the projects. 
The analysed projects created the following means: the shopping mall (and reconstructed streets nearby), the water park and spa complex and the marketplace. The opportunity aspect of the framework showed that all three projects made some kind of opportunities available. The shopping mall allowed the opportunity to go shopping in modern and comfortable environment, to park the car near the city centre and to use it as a community space.

“An opinion showed up, that this shopping mall wasn't necessary for the city. But this is probably not true

because there was a market demand. People are looking for a certain service level and there was a demand for developing the infrastructure too." [V28, politician]

The water park and spa brought about the capability of swimming and other recreation activities.

"The spa complex is valuable in itself, the fact that there is this opportunity in town is valuable. Especially

for families with kids. Slides, slides and slides are the three most important advantages of the complex." [V19, user]

The renewed marketplace allowed people to do the shopping in modern environment and to use a special community space and get connected with sellers.

"Lot of people said that the marketplace became prettier. This is one aspect, the aesthetic one." [V8, civil activist]

In case of the shopping mall the opportunity aspect also highlighted that retailing outside of the mall (in the city centre) became much harder. Local inhabitants with an average income, especially pensioners stayed out of using the mall. Interviewees missed the opportunity to preserve the features of the old hemp-spinning factory, which was totally destroyed during the construction. Some of the interviewees also missed the opportunity of real participation in the planning process.

"The shopping mall destroyed the city centre. The retailers in city centre should have been asked about this." [V23, civil activist]

"Before they signed the conservation agreement on the old hemp-spinning factory, they [the investors] already had demolished the building. The chief architect - or whoever - should have questioned this. But the capitalist ambition was operating. " [V21, civil activist]

In the case of the water park and spa, the neighbouring campsite on the riverside became unusable because the wells of the old campside were attached to the new spa and the camping remained practically without water. Some of the interviewees argued that it would have been much more useful to renovate the old campsite than to build a new and expensive water park and spa, because the camping, which also has swimming pools, could provide cheap recreation services for local inhabitants.

"There was some kind of spa-building »frenzy" in Hungary, that is why a lot of spas were built. This was the trend for a while [...] Three of the five biggest water parks of Europe are in Hungary. " [V19, user] 
"The campsite was crushed by the new spa because the remaining territory cannot be used for camping, it would be uneconomical." [V22, politician]

According to some of the interviewees, local inhabitants complained about the scarcity of swimming pools for sports in town. Hence, the city needed a swimming pool for sport instead of an expensive water park and spa complex. In other words, while the opportunities of having a thermal bath or enjoying the slides have widened, the opportunity to pursue swimming as sport has shrunken.

"The public functions disappeared from the scope of services [of the spa], there are completely different users now. It does not have the conventional swimming pool function anymore; the goal is to attract exclusive guests. I don't know, where the locals can go if they just want to swim." [V8, politician, civil activist]

Interviewees missed the unified cityscape, the traditions connected to the river and the partnership in the process.

"They [the decision-makers] didn't listen to the professional arguments during the process. It was a makebelieve consultation, they didn't take it seriously." [V17, expert]

In the case of the marketplace, part of the local society was crowded out of the new marketplace, especially pensioners and people with low-income. Local inhabitants missed the real sense of a marketplace selling "lángos" (a Hungarian local speciality similar to fried dough) as well as old local retailers and producers.

"They took away that feature of the old marketplace, where old pensioners could put out some eggs, parsley and a chicken for sale; they sell everything and out of the same money do the shopping there." [V7, user]

Some of the interviewees stated that the infrastructure does not meet the requirement of a well-functioning marketplace and that the retailers of the old market were left out from the development project.

"The practice of the city council is limited to the minimum mandatory [participatory] processes prescribed by the law. It does not meet the standards of European Union or the norms of the quoted development policy documents." [V8, politician civil activist]

Conversion factors were very similar in all of the cases. Low income of local inhabitants, lack of necessary rules, lack of unified cityscape, inadequate handling of common wealth.

"They should figure out what is the function of the city centre. [...] The same is true for the riverside. There is no unified conception about it. They pretend liberalism, but in fact, it is just poorly conceived." [V13, expert]

In the case of the marketplace the set of conversion factors was larger. On top of low income and inadequate handling of common wealth, small room, rules for primary producers, proximity of the bus station and the shopping mall, knowledge about the necessary 
regulations and the lack of transparency during planning could also be identified as conversion factors. The results of the opportunity aspect are summarized in Table 1.

"One of the biggest problems is that the primary producers are not forced into competition. How does it look like, that somebody is allowed to vend for free [without having to pay rental] in the market while others are not? This is exactly the opposite of the concept of market." [V10, expert]

"The plans about the market changed almost every month." [V1, civil activist]

"It cannot be expected from a simple merchant to run around with the Civil Code under her arm." [V6, civil activist]

Table 1 Opportunity aspect of case studies

\begin{tabular}{|c|c|c|c|}
\hline & Shopping mall & Water park and spa & Marketplace \\
\hline Means & $\begin{array}{l}\text { Building of the } \\
\text { shopping mall, Streets } \\
\text { beside the shopping } \\
\text { mall }\end{array}$ & $\begin{array}{l}\text { Water park and spa } \\
\text { complex }\end{array}$ & $\begin{array}{lr}\text { Market } & \text { halls, } \\
\text { Marketplace, } & \text { Parking } \\
\text { lot }\end{array}$ \\
\hline $\begin{array}{l}\text { Available doings and } \\
\text { beings }\end{array}$ & $\begin{array}{l}\text { Shopping in a modern, } \\
\text { comfortable shopping } \\
\text { mall, Parking near the } \\
\text { city centre, } \\
\text { Using community } \\
\text { space. }\end{array}$ & $\begin{array}{l}\text { Swimming, Using } \\
\text { slides. }\end{array}$ & $\begin{array}{l}\text { Shopping and buying } \\
\text { food, Enjoying } \\
\text { community space. }\end{array}$ \\
\hline Opportunity-gap & 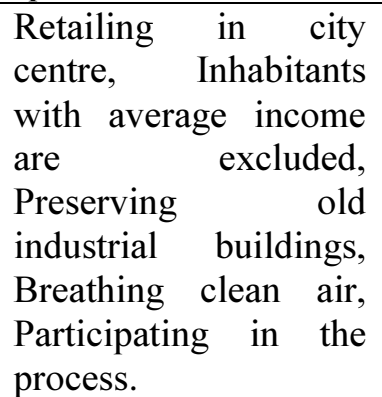 & $\begin{array}{l}\text { Using the riverside } \\
\text { near the spa for } \\
\text { recreation, Swimming } \\
\text { as a sport, Having } \\
\text { unified cityscape, } \\
\text { Participation in the } \\
\text { process. }\end{array}$ & $\begin{array}{l}\text { Inhabitants with low } \\
\text { income are excluded, } \\
\text { Having the „real sense } \\
\text { of a marketplace”, } \\
\text { Using the building in } \\
\text { an appropriate way. }\end{array}$ \\
\hline Conversion factors & $\begin{array}{l}\text { Income, Lack of } \\
\text { regulations and a } \\
\text { unified concept of the } \\
\text { cityscape. }\end{array}$ & $\begin{array}{l}\text { Income, Lack of } \\
\text { regulations and a } \\
\text { unified concept of the } \\
\text { cityscape. }\end{array}$ & $\begin{array}{l}\text { Income, Regulations } \\
\text { about primary } \\
\text { producers, Bus station, } \\
\text { Being familiar with } \\
\text { regulations, } \\
\text { Complicated } \\
\text { development process }\end{array}$ \\
\hline
\end{tabular}

Source: own compilation

The second building block of the analytical framework is the process aspect. The first element of the process aspect, the values are different in each case. Conflict between the different values was most conspicuous in the case of the shopping mall. Here economic efficiency conflicted with the value of preserving an industrial monument (the building of the old hemp-spinning factory).

"Is there a profitable function of an old building at all? Should it be a university or a library? It could have been a community function, but if everything has community functions, then it will not be sustainable in the middle- or longrun. For me, it was an acceptable compromise." [V28, politician] 
Furthermore, there were different opinions about taking responsibility for certain actors' economic situation. According to an opinion, it is the task of the decision-makers to support the retailers in the city centre in the market competition. But another opinion emphasised that it is the retailers' responsibility to adapt to the new circumstances brought about by the shopping mall.

\footnotetext{
"In my opinion, they killed the retailers in the city centre. Only active support could put them back into position." [V23, civil activist]

"They [the retailers in the city centre] need to adapt. If they sold "gadget" until now, then they should sell "widget " from now on." [V21, civil activist]

In the case of the water park and spa, values about common wealth were decisive.

"The whole project masks the sale of a public property that is situated near the city centre, which is one of the most valuable assets of the town, without competition; thus bypassing the regulation of property management." [V9, politician, civil activist]
}

Different values about the role of the marketplace played an important role in the decisionmaking about the infrastructure. On the one hand, a market is similar to a shopping mall: you can buy all kinds of goods from vegetables to bedroom furniture. On the other hand, a market is a special community space, where you can buy fresh groceries usually from the producers themselves, you can have a chat with friends and you can have a nice lunch of "lángos" (fried dough) or of sausages.

\footnotetext{
"We have to compete with multinational companies. [...] As a matter of fact, they [the buyers] just have to adapt to the fact that there are not just groceries here but clothing, furniture and bathroom apparel as well." [V2, expert]

"It would really matter, if the attitude of the management changed, if it was a high-standard producers' market, also providing an opportunity for a leisure activity: you can go shopping and also have "kürtös kalács" [a special Hungarian sweet bread]. But here, it is not allowed to roast the meat on a barbecue tray, though it would attract customers. " [V7, user]
}

The most important decisions about the development projects were made in closed spaces. The most influential actors were the city council, the investors and other public bodies such as the National Development Agency or the National Public Health and Medical Officer Service. The hidden forms of decisions, i.e. those players, who can shape the agenda of decisionmaking, also had an influence in all of the cases. This result is supported by the fact that there were hardly any debates during city council meetings, the members of the city councils often referred to opinions of other actors, especially experts. Because of these hidden forms of power certain members of the city council looked for additional channels - like bottom up initiatives - to enforce their interests and express their opinions.

\footnotetext{
"The city council, the public procurement procedure and the local regulations all affected the project. Commissions [of the city council] as well. We had to ram the costs down the throat of the city council." [V3, expert]
} 
Activities of citizens primarily took place in claimed spaces. The communication with the stakeholders of the projects was limited to unidirectional forms (e.g. providing information at residential forums or info texts on websites). And in most of the cases, the provided set of information was not comprehensive.

"We cannot really talk with the management of the marketplace; they have an excuse for everything. Once, we got together with the Agricultural Association and 20-25 producers but to no avail." [V7, civil activist]

Civic activists claimed space for themselves through press conferences, by collecting signatures, or launching petitions. For instance, civic cooperation was set up to save the building of the old hemp-spinning factory; a petition was launched by the city centre retailers against the shopping mall, and civic activists collected signatures for reconsidering the plans of the marketplace. The results of the process aspect are summarized in Table 2.

Table 2 Process aspect of case studies

\begin{tabular}{|c|c|c|c|c|}
\hline & & Shopping mall & $\begin{array}{l}\text { Water park and } \\
\text { spa }\end{array}$ & Marketplace \\
\hline \multirow{3}{*}{ Agency } & Closed spaces & $\begin{array}{l}\text { City council, } \\
\text { Investors }\end{array}$ & $\begin{array}{l}\text { City council, } \\
\text { Investors }\end{array}$ & $\begin{array}{l}\text { City council, Head } \\
\text { of the project- } \\
\text { company, Regional } \\
\text { authorities }\end{array}$ \\
\hline & Invited spaces & $\begin{array}{l}\text { Architects, } \\
\text { Designers, Local } \\
\text { media }\end{array}$ & $\begin{array}{l}\text { Architects, } \\
\text { Designers, Real } \\
\text { estate experts, } \\
\text { Water } \\
\text { management } \\
\text { experts }\end{array}$ & $\begin{array}{l}\text { Staff of the local } \\
\text { government, } \\
\text { Architects, } \\
\text { designers, } \\
\text { Merchants }\end{array}$ \\
\hline & Claimed spaces & $\begin{array}{l}\text { Civil collaboration } \\
\text { for the hemp- } \\
\text { spinning factory } \\
\text { building, Petition } \\
\text { of the retailers in } \\
\text { city centre. }\end{array}$ & $\begin{array}{l}\text { Collection of } \\
\text { signatures for } \\
\text { petitions by a local } \\
\text { NGO, Official } \\
\text { prosecution, } \\
\text { NGO's protests } \\
\text { and press } \\
\text { conferences. }\end{array}$ & $\begin{array}{l}\text { Civil suits of the } \\
\text { owners of kiosks } \\
\text { and } \\
\text { Collection stalls, } \\
\text { signatures for a } \\
\text { petition by a local } \\
\text { NGO. }\end{array}$ \\
\hline \multicolumn{2}{|c|}{ Values made explicit } & $\begin{array}{l}\text { Efficiency and } \\
\text { income growth } \\
\text { versus preserving } \\
\text { cultural heritage, } \\
\text { Taking } \\
\text { responsibility for } \\
\text { those falling behind } \\
\text { in the market }\end{array}$ & $\begin{array}{l}\text { Income generation } \\
\text { versus providing } \\
\text { cheap services to } \\
\text { local inhabitants }\end{array}$ & $\begin{array}{l}\text { Importance of } \\
\text { primary producers } \\
\text { versus importance } \\
\text { of retailers }\end{array}$ \\
\hline
\end{tabular}

Source: own compilation

On the whole, we found two very different perspectives about participation. Actors with access to closed spaces argued that participation does not have too much sense, due to the lack of demand for it; and due to the fact that people do not have enough competence or they 
cannot agree on anything at all. On the other side, stakeholders who mainly operated in claimed spaces argued that they were left out of the processes and their efforts seemed to be pointless for themselves.

Another general phenomenon was that public participation took place too late. Civil activists drew attention to opportunity-gaps in connection with the analysed development projects, but usually their reactions were belated. By the time civil activist managed to claim spaces for themselves, the most important decisions had already been made in the closed spaces.

\section{CONCLUSIONS}

The present paper argues that the capability approach provides a meaningful alternative to the dominating competitiveness or growth-centred views for understanding and evaluating local development projects. We argue that relying on the capability approach provides significant advantages: (1) it gives a substantive meaning to well-being (2) and utilizes an informational basis for the analyses that is wider than the usually considered set of information, and therefore more adequate to assess the effects of the development projects on well-being. The capability approach emphasizes the actual freedom of local inhabitants to achieve doings and beings, which people have reasons to value. We elaborated an analytical framework in order to evaluate local economic development projects and applied this framework for three cases in Szeged, Hungary.

The paper contributes to an emerging stream of literature that attempts to approximate regional science with the capability approach literature, in order to provide a deeper understanding of the link between local development and the well-being of the citizens. On this basis, it developes a framework that gives equal attention to the process aspect of local development instead of just focusing on its outcomes.

During the empirical analysis, the capability approach based perspective sheds light on a number of factors that may hinder the capacity of development projects to increase the wellbeing of citizens. It makes clear that providing means (e.g. a new marketplace, a water park or a shopping mall) for the citizens does not imply that they will actually be able to use these means to achieve valuable doings and beings.

The analysed cases reflect the logic of the "urban growth machine": their most important focus was how to generate income in the city and how to establish physical infrastructure and 
the necessary business climate for a growing economy. On the whole, they treated stakeholders as "patients", as passive recipients of development.

From the capability perspective it becomes clear, that these projects had complex impacts on the city: they made various opportunities available, but also destroyed some important ones. The evaluative framework identifies the conversion factors, which influenced the use of the realized infrastructure. These are typically the level of income, the lack of unified cityscape and indistinct decision-making mechanisms. The most important decisions were made in closed spaces, where hidden forms of power had special influence. Civil activism in connection with the projects took place in claimed spaces.

Thus the rich informational basis of the capability-based perspective helps to identify the places for intervention, namely the conversion factors, the barriers, which prevent people from actually using the given means (the results of the development projects). It also reveals the lacking opportunities of local inhabitants. Therefore, the additional set of information taken on board by the capability approach (compared to the competitiveness-centred view) seems to be relevant and necessary for planning and evaluating local development initiatives.

\section{Acknowledgement}

We are thankful to János Tözsér for his useful comments and support. This work was supported by Hungarian Scientific Research Fund [grant number K-109425]

\section{REFERENCES}

Alkire, S. (2007). Why the Capability Approach? Journal of Human Development, 6(1), 115135.

Arnstein, S. R. (1969). A Ladder of Citizen Participation. Journal of American Planning Association, 35(4), 216-224.

Bajmócy, Z., \& Gébert, J. (2014). Arguments for Deliberative Participation in Local Economic Development. Acta Oeconomica, 64(3), 313-334.

Begg, I. (1999). Cities and Competitiveness. Urban Studies, 36(5-65), 795-809.

Biggeri, M., \& Ferrannini, A. (2014a). Opportunity Gap Analysis: Procedures and Methodes for Applying the Capability Approach in Development Initiatives. Journal of Human Development and Capabilities, 15(1), 60-78.

Biggeri, M., \& Ferrannini, A. (2014b). Sustainable Human Development. A New Territorial and People-Centred Perspecitve. New York: Palgrave Macmillan.

Blaikie, N. (2000). Designing Social Research. Cambridge: Wiley.

Brinkmann, S., \& Kvale, S. (2015). InterViews. Learning the Craft of Qualitative Research Interviewing (3rd ed.). Los Angeles - London - New Delhi - Singapore - Washington DC: Sage.

Capello, R. (2009). Space, Growth and Development. In R. Capello \& P. Nijkamp (Eds.), Handbook of Regional Growth and Development Theories (pp. 33-52). Cheltenham Northampton: Eward Elgar.

Cotula, L. (2008). The Property Rights Challenges of Improving Access to Water for Agriculture: Lessons from the Sahel. Journal of Human Development, 9(1), 5-22. 
Cox, K. R. (1995). Globalization, Competition and the Politics of Local Economic Development. Urban Studies, 32(2), 213-224.

Crocker, D. A. (2007). Deliberative Participation in Local Development. Journal of Human Development and Capabilities, 8(3), 431-455.

Easterlin, R. A. (1974). Does Economic Growth Improve the Human Lot? Some Empirical Evidence. In P. A. David \& M.W.Reder (Eds.), Nations and Households in Economic Growth: Essays in Honour of Moses Abramowitz. New York, London: Academic Press.

Frediani, A. A. (2007). Amartya Sen, the World Bank, and the Redress of Urban Poverty: A Brazilian Case Study. Journal of Human Development, 8(1), 133-152.

Frediani, A. A. (2010). Sen's Capability Approach as a framework to the practice of development. Development in Practice, 20(2), 173-187.

Frediani, A. A., Boni, A., \& Gasper, D. (2014). Approaching Development Projects from a Human Development and Capability Perspective. Journal of Human Development and Capabilities, 15(1), 1-12.

Gaventa, J. (2006). Finding the spaces for change: a power analysis. IDS Bulletin, 37(6), 2333.

González, A. H., Aristizábal, A. B., \& Díaz, R. M. (2008). Potentialities of the capability approach in impact assessment of technology-based development aid projects: the case of micro hydro power in Andean Bolivian communities. Paper presented at the 5th Annual Conference of the HDCA.

Greenwood, D. T., \& Holt, R. P. F. (2010). Local Economic Development in the 21st Century. Armonk, London: M.E. Sharpe.

Hartono, M. D. (2012). The Synergy of a Capability Approach and a Human Rights-based Approach to the Post-disaster Reconstruction: case of Mt. Merapi's Eruption in Indonesia. Paper presented at the 9th Annual Conference of HDCA.

Hausman, D., \& McPherson, M. (1997). Economic Analysis and Moral Philosophy. Cambridge: Cambridge University Press.

Hodgett, S. (2008). Sen, Culture and Expanding Participatory Capabilities in Northern Ireland. Journal of Human Development and Capabilities, 9(2), 165-183.

Kerstenetzky, C. L., \& Santos, L. (2009). Poverty as Deprivation of Freedom: The Case of Vidigal Shantytown in Rio de Janeiro. Journal of Human Development and Capabilities, 10(2), 189-211.

King, G., Keohane, R. O., \& Verba, S. (1994). Designing Social Inquiry, Scientific inference in qualitative research. Princeton: Princeton University Press.

Kirkpatrick, L. O., \& Smith, M. P. (2011). The Infrastructural Limits to Growth: Rethinking the Urban Growth Machine in Times of Crisis. International Journal of Urban and Regional Research, 35(3), 477-503.

Lever, W. F. (1999). Competitive Cities in Europe. Urban Studies, 36(5-6), 1029-1044.

Lukes, S. (1974). Power: A Radical View. London: Mcmillan.

Maier, K. (2001). Citizen Participation in Planning: Climbing a Ladder? . European Planning Studies, 9(6), 707-719.

Mayo, M. (2004). Exclusion, Inclusion and Empowerment: Community Empowerment? Reflecting on the Lessons of Strategies to Promote Empowerment. In J. Andersen \& B. Siim (Eds.), The politics of Inclusion and Empowerment: Gender, Class and Citizenship: Aalborg University.

Nieto, P. B., \& Munoz, I. (2012). A step towards development and freedom for the Peruvian rural highlands: the case of Sierra Productiva. Paper presented at the 9th Annual Conference of the HDCA. 
Nussbaum, M. (2011). Creating capabilities: the human development approach. Cambridge, Mass.: Belknap Press of Harvard University Press.

Pellissery, S., \& Bergh, S. I. (2007). Adapting the Capability Approach to Explain the Effects of Participatory Development Programs: Case Studies from India and Morocco. Journal of Human Development, 8(2), 283-302.

Pretty, J. N. (1995). Participatory learning for sustainable agriculture. World Development, 23(8), 1247-1263.

Rippin, N. (2016). Multidimensional poverty in Germany: A capability approach. Forum for Social Economics, 45(2), 3230-255.

Schischka, J., Dalziel, P., \& Saunders, C. (2008). Applying Sen's Capability Approach to Poverty Alleviation Programs: Two Case Studies. Journal of Human Development, 9(2), 229-246.

Sen, A. K. (1995). Inequality Reexamined. Cambridge: Cambridge University Press.

Sen, A. K. (1999). Development as Freedom. Oxford: Oxford University Press.

Sen, A. K. (2005). On Ethics and Economics. Oxford: Blackwell Publishing.

Stiglitz, J. E., Sen, A., \& Fitoussi, J.-P. (2009). Report by the commission on the

measurement of economic performance and social progress. Paris: Commission on

the Measurement of Economic Performance and Social Progress, 2009.

http://www.stiglitz-sen-fitoussi.fr/en/index.htm

Swinburn, G., Goga, S. E., \& Murphy, F. (2006). Local Economic Development: A Primer. Developing and Implementing Local Economic Development Strategies and Action Plans. Washington: The World Bank.

Vizard, P., \& Speed, L. (2016). Examing multidimensional inequality and deprivation in Britain using the capability approach. Forum for Social Economics, 45(2-3), 139-169. 